\title{
Needs of Agriculture Development for Sustainable Living Communities
}

\section{Salah Arafa*}

Professor of Physics, School of Sciences and Engineering, the American University in Cairo, EGYPT and Fellow Professor of Renewable Energy and Sustainable

Development, Stromstad Academy, Stromstad, Sweden

*Corresponding Author: Salah Arafa, Professor of Physics, School of Sciences and Engineering, the American University in Cairo, EGYPT and Fellow Professor of Renewable Energy and Sustainable Development, Stromstad Academy, Stromstad, Sweden.

Agriculture Development is well recognized as the core for Global Sustainable Development. Its importance and influence on Food Security, Health, Environmental Security, and National Security is well researched and established.

The pillars needed for Agriculture Development are:

- Transfer of Knowledge to Farmers

- Utilization of Renewable Energy Technologies

- Community-Based Education and Training for Development

- Access to Finance, Markets, and Public Services

- Good Governance

We need to improve the productivity of the farm land and to support the cultivation of the desert land to guarantee success in eradication of poverty, achieving our SDGs, and building sustainable living communities.

The urgency to plan, construct, and develop sustainable living communities [SLC] have been recognized for a long time all over the world. The integrated approach, however, has not been yet optimally pursued. The understanding and the correlation between Agriculture, Environment, Health, Industry, Energy, and Development is needed in order to make a progress and to achieve the Global Sustainable Development Goals.

The existence of quality human resources is a necessity for any development process to continue successfully. Learning Science and new technologies is important for all participating in the de-
Received: December 24, 2020

Published: February 15, 2021

(C) All rights are reserved by Salah Arafa. velopment processes at the community level. The best approach for a better understanding of the public about new technologies was found to be the open public dialogues at the community level with the participation of all stakeholders. For the effective planning and management of such community-based educational programs, it was also found that well informed and skilled local personnel should be also trained to be involved in decision-making process through a local NGO.

Prospects on the development of proper approaches and programs at the community level are presented and discussed. Many problems and challenges faced by the population of such rural communities find solutions in the use of renewable energy technologies. Examples on how to involve all community members in the planning, implementation, and evaluation of the communitybased projects and programs as well as the public open dialogues and awareness programs for the public will be also presented.

The implementation of renewable energy technologies to overcome some of the barriers faced by rural villages and desert communities in Egypt and to achieve poverty reduction, social justice, and sustainable development was field tested in 3 communities in Egypt.

Our experiences gained over more than 45 years of working in the field of utilization of renewables and other technologies in Basaisa Village, Al-Sharkiya Governorate (Started in 1974) [www. 
google.com/BasaisaVillage ]; in the New Basaisa community, South Sinai Governorate (Started in 1991) [www.google.com/NewBasaisaCommunity]; and in the Valley Paradise Community, New Valley Governorate (Started in 2018) in Egypt towards achieving community-based and citizen-centered sustainable development will be presented in details in later issues of ASAG.

All our field work also addresses how such interventions improved the human wellbeing and empowered poor citizens and communities to achieve sustainable development.

Field experiences showed that open free dialogues with all stakeholders, site-specific education and training, appropriate local financing systems, and access to knowledge are key-elements and essential factors for achieving green economy and sustainable community development.

Let us call for help and ask our children, our friends, our colleagues, and contacts to PLANT A TREE (in a Farm - in the Garden - in the Street - in Windows - on the Roof of the Building). This will save our Earth, Protect our Environmental Security, and Greening our Economy, and Achieve Enjoying Healthy Life in Sustainable Living Communities.

All practical studies and field experiences indicate the importance of developing community-based education, training, and technical assistance to inhabitants especially youth and women helping them to start operating home-based crafts, processes, productive enterprises for income generating activities and economic development.

The general vision developed over the years can be expressed here as: Children... Are the Future of Our Nations

- $\quad$ Renewables...Are the Future of Our Planet

- Good Governance and Social Responsibility...Guarantee Our Environmental Security

- Quality Education, Training, and Innovation...Are Our Way to Achieve Sustainable Future
Finally, no one, no community, and no country can do it alone. Partnerships and cooperation, particularly with local NGOs, Alliances, and private sector social responsibility actors, are critical in all cases.

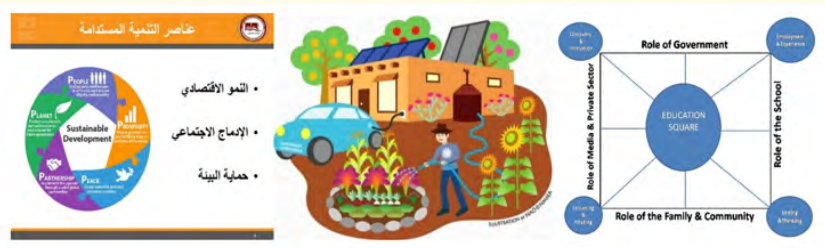

Figure 1: The integrated approach used in our field works.
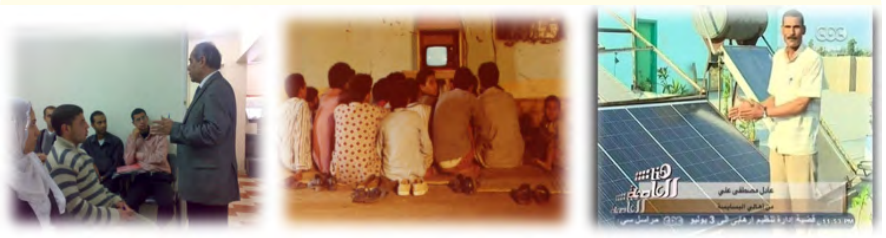

Figure 2: Basaisa Village - Alsharkiya Governorate, Egypt.
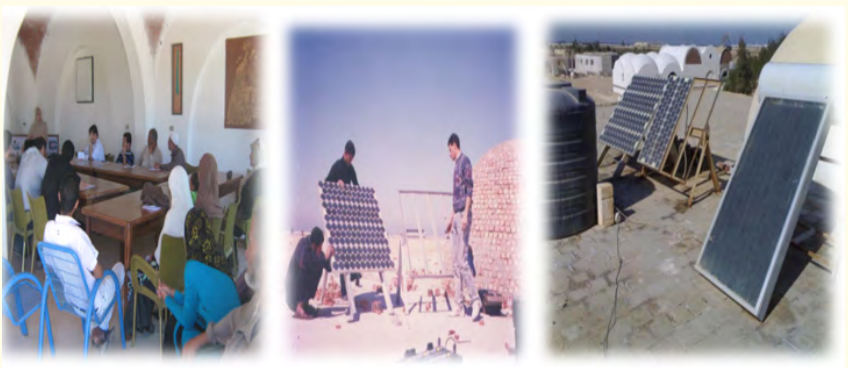

Figure 3: New Basaisa Community - South Sinai Governorate, Egypt.
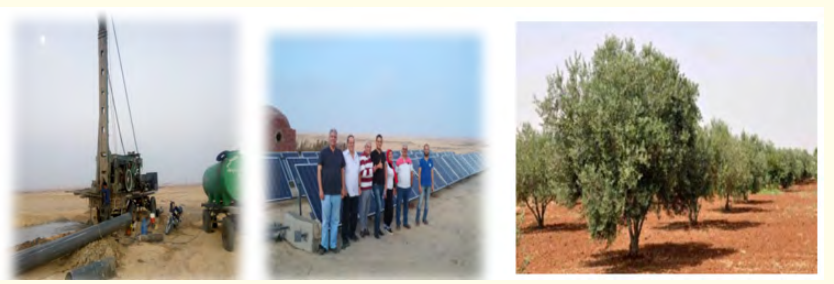

Figure 4: Valley Paradise - New Valley Governorate, Egypt. 
For more information and knowledge: search for salah ARAFA

AUC renewable energy and community development in www. google.com/.

\section{Assets from publication with us}

- Prompt Acknowledgement after receiving the article

- Thorough Double blinded peer review

- Rapid Publication

- Issue of Publication Certificate

- High visibility of your Published work

Website: www.actascientific.com/

Submit Article: www.actascientific.com/submission.php

Email us: editor@actascientific.com

Contact us: +919182824667 